\title{
Immigration and linguistic diversity: a new and poorly understood situation for Catalan ${ }^{1}$
}

Pere Comellas Casanova

Grup d'Estudi de Llengües Amenaçades (GELA), Universitat de Barcelona

Corresponding author. Email: perecomellas@ub.edu. Postal Address: Departament de Filologia Romànica. Universitat de Barcelona. Gran Via de les Corts Catalanes, 585. 08007 Barcelona.

\begin{abstract}
For decades Catalan, a language minoritized and endangered by the hegemony of other state languages, has been experimenting with a process of revitalization driven by social activism and political autonomy, which has been particularly strong in some of its historical regions. Recently, however, serious doubts about the success of this process have been heightened due to a surge of immigrants that speak neither Catalan nor Spanish. This article attempts to assess the impact of immigrant languages on the future of the linguistic dynamic using demographic evidence. We raise the question of whether this is a key factor to Catalan's survival, and finally demonstrate that the underestimation of alloglots in statistical studies is an indicator of the need to expand the study of the phenomenon of the new linguistic diversity, which exceeds the traditional framework of bilingual settings.
\end{abstract}

Key words: revitalization, Catalan language, immigrant languages, minority languages, multilingualism

\section{The new demo-linguistic context: recent immigrants to the Catalan-speaking lands}

Ever since Fishman (1991) described Catalan as a successful example of language revitalisation ('relatively' successful, as he put it), many authors have agreed with him. According to Mollà (2006: 393), for example:

All the experts who study the case of Catalan concur in pointing out that it is one of the most successful cases of language normalisation, that is, of a reversal in the process of language shift, and they situate Catalonia in stage 1 on Fishman's scale - the most positive one for a threatened language.

Juarros-Daussà and Lanz (2009: 1) agree: 'The autonomous region of Catalonia is seen by many today as one of the most successful examples of language policy application over the past three decades', as do others. Nevertheless, it must be emphasized that most of those statements just talk about Catalonia, as Strubell (2001: 275) points out: 'There seems to be no reason for placing Catalan in Catalonia anywhere other than at Stage 1. However, in the

\footnotetext{
${ }^{1}$ This paper is part of a research project "Intergenerational linguistic transmission of alloglot languages in Catalonia", funded by the Spanish Ministerio de Economía y Competitividad (FFI2013-47768-P).
} 
Balearic Islands and Valencia, where well over a third of Catalanspeakers live, the Intergenerational transmission of Catalan foreseen at Stage 6 and above is certainly not guaranteed at present in urban areas'.

Despite these internal imbalances, from a global perspective, Catalan is certainly a fine example of language vitality. It is unquestionably in a highly advantageous position compared with most of the world's languages, particularly non-hegemonic languages in a state. Unfortunately, this only reveals the dramatic future prospects of many of these languages.

However, this relatively sound position is no great consolation for many Catalan speakers, who continue to feel that their language's future is not guaranteed. What is more, it is important to note that researchers often talk about Catalonia instead of the entire historically Catalan-speaking territory, which is anything but homogenous. So we are at a strange juncture. First, surveys and official studies usually offer positive interpretations of the situation (Secretaria de Política Lingüística 2009; Pradilla \& Sorolla 2012). However, numerous Catalan speakers, particularly in certain areas within the linguistic domain, believe that they are witnessing a gradual drop in the use of their language:

The problem came when we were told, statistics in hand, that we are not faring badly at the same time that many people are noticing that they are hearing less and less Catalan on the street and in its domain. (Aymà 2010: 29)

It is in this context that, in recent years, many of the historically Catalan-speaking lands have also received large numbers of immigrants, so intense a phenomenon that it has profoundly altered their demo-linguistic composition. Until close to the end of the $20^{\text {th }}$ century, the proportion of speakers of a first language other than Catalan or Spanish was quite low, even though since the 1970s there had been a considerable community whose first language was Tamazight and/or Darija. However, in the waning years of the $20^{\text {th }}$ century and the first decade of the $21^{\text {st }}$ century, the scenario has shifted. Figure 1 illustrates the great demographic change that has occurred recently. We can assume a similar linguistic change for the three autonomous communities where Catalan is a co-official language.

\section{[FIGURE 1 NEAR HERE]}

Figure 1: Evolution in the number of foreigners with a certificate of foreign registration or foreign residence card valid on the $31^{\text {st }}$ of December each year. Based on figures from the Secretary of State for Immigration and Emigration (<http://extranjeros.mtin.es/es/InformacionEstadistica/>).

Figure 2 shows that the net population increase in the three autonomous communities in Spain is primarily due to the non-Spanish population: 
[FIGURE 2 NEAR HERE]

Figure 2: Overall population with Spanish and non-Spanish citizenship in the autonomous communities of Catalonia, the Balearic Islands and Valencia.

This situation is much more accentuated if we only consider the 16 to 44 age bracket, i.e. the fertile ages. In fact, in this age bracket, the population with Spanish citizenship drops. Therefore, all the absolute population growth in this bracket is due to individuals with foreign citizenship.

A graphic representation of the percentage of the population with foreign citizenship (Figure 3 ) confirms their quantitative importance. The present and future impact of this trend is predictable if we bear in mind that almost one out of every four residents of the Catalanspeaking communities in Spain between the ages of 15 and 44 is foreign:

\section{[FIGURE 3 NEAR HERE]}

Figure 3: Percentage of the non-Spanish population aged 15 to 44 and total population in the autonomous communities where Catalan is an official language. Based on the ongoing census of the National Statistical Institute.

However, the diversity of the immigrant population is quite accentuated in all senses. First, this average compared to the population as a whole is divided quite unevenly, as the population of some towns is more than $50 \%$ foreign, whereas in others there is not a single foreigner registered in the census (although both extremes are exceptional). Likewise, there are also vast differences in the distribution of their home countries: from the southernmost reaches of the region of Valencia, where there are large percentages of other Europeans, to the town of Salt, where almost one-third of the population is from Africa (half of whom are Moroccan).

What is more, we know that the immigrants speak dozens of languages that come from very different sociolinguistic contexts, ${ }^{2}$ with differences in social status that can become extreme and with widely divergent levels of education and school systems: from multilingual farm labourers who can speak several African languages and a couple of colonial languages to monolingual Japanese managers; from illiterate speakers of minority languages to Chinesespeaking academics (or vice versa). These variables and many more condition linguistic attitudes and behaviour and determine which

\footnotetext{
2 In 2005 the Grup d'Estudi de Llengües Amenaçades (GELA -- Threatened Languages Study Group) of the University of Barcelona organised an exhibition on the results of the field work undertaken to identify speakers of other languages in Catalonia. At that time there were 208 languages recorded (Junyent 2005: 166); today, there are 283 (http://www.gela.cat/doku.php?id=Ilengues). In 2010 the Grup de Recerca Sociolingüística de les Illes Balears (GRESIB - Sociolinguistic Research Group of the Balearic Islands) from the University of the Balearic Islands drew up the inventory of immigrants' languages in the Balearic Islands and found 144 of them (http://www.uib.cat/depart/dfc/gresib/llengues/presentacio.htm). In addition, a 2006 study of the languages spoken by residents of Lleida found 63 in the city alone (Òmnium Cultural 2006). See also Barrieras 2013.
} 
language variety or varieties they transmit and with which associated ideologies and values. For example, we can often relate given linguistic behaviour with certain groups and origins. There are cultural traditions that are more accustomed to language contact, continua and linguistic diversity, and others that are much more highly influenced by longer-term monolingual ideologies. At the same time, for a variety of reasons, such as demographic structure, not all origins have the same capacity to project into the future linguistic uses and representations. In this vein, we can note curious phenomena in all the Catalan-speaking lands. Figures 4 and 5 illustrate the age pyramids of the Moroccan and German populations in the region of Valencia in 2010:

\section{[FIGURE 4 NEAR HERE]}

Figure 4: Population pyramids of the Moroccan population in the region of Valencia (2010). Drawn up with figures from the National Statistical Institute.

\section{[FIGURE 5 NEAR HERE]}

Figure 5: Population pyramids of the German population in the region of Valencia (2010). Drawn up with figures from the National Statistical Institute.

In the Moroccan population, the largest group is men between the ages of 25 and 30, and there are many children under the age of four. However, the German population is rather elderly, more balanced in terms of the sexes and includes almost no children. The imbalance between men and women in the fertile age brackets has to have important consequences for language transmission, since it would drive these males to reproduce outside their own group. Figure 6 shows the superimposition of the age pyramids for Chinese (white) and Pakistanis (black) in Catalonia in 2010. Once again we find two totally different age structures. While the Chinese pyramid is wellbalanced (which in theory encourages group maintenance), the Pakistani pyramid is exaggeratedly imbalanced in favour of men. In the absence of information on other dynamics that might offset this imbalance, we could predict a high degree of mixed marriage among people of Pakistani origin.

\section{[FIGURE 6 NEAR HERE]}

Figure 6: Superimposed population pyramids of the Pakistani community (black) and the Chinese community (white) in Catalonia in 2010 (the superimposed zones in grey)

On the basis of these demographic indices (of which we only show a sample), we think it licit to suppose that we are facing a (relatively) new demo-linguistic situation, i.e. the great linguistic diversity of the population. Our hypothesis is that this factor could be key to the demo-linguistic future of the Catalan lands, as we will try to explain in Section 2 of this article. Therefore, to grasp and be able to put forward hypotheses on the transmission of languages and 
language ideologies, we have to bear in mind this vast diversity. Many different variables need to be combined: age, sex, native language or languages, the size of the communities, intercommunication and social networks, contact with home and internal organisation, among others. This knowledge should enable us to understand and recognise what immigration brings, in order to properly evaluate it. The lack of figures and the projection of prejudices have led to errors that a linguistically abused community like Catalan speakers should not have made: for example, taking into account only the official language of the country of origin when planning measures for integration at school:

[...] It is not surprising that, on the question of identifying the language and culture of children, the host states followed the options of the states of origin. This led to the absurd situation of teaching classical Arabic to children who spoke Tamazight (Berber) as their mother tongue, supposedly to assist their integration into school and help them maintain contacts with the culture of their country of origin. (Tilmatine 2002-2003: 269)

On the other hand, projecting our own values on the role of languages onto other communities without making distinctions can also be an error. Not all linguistic communities represent their own language or languages in general in the same way. They do not all share the identifying value of the language that exists in the Catalanspeaking areas. Thus, it is not surprising that teachers in Catalonia project their own linguistic representations onto students speaking another minoritized language, without bearing in mind that the symbolic role of those students' language might be radically different, in spite of certain supposed similarities in the socio-linguistic situation. In addition to research, we also need a less self-centred perspective that is more mindful of diversity.

\section{Alloglots, a key factor in the survival of Catalan?}

The large proportion of recent immigrants in regions where Catalan has historically been spoken has sometimes been interpreted as a serious new threat to the survival of Catalan. In fact, according to Ros (2006: 53), international migratory flows foster a language imbalance in favour of the hegemonic languages:

From a macro standpoint, the phenomenon of transmigration - the movement of people around the world - points towards a greater preference for the use of majority languages (like Spanish) instead of minority languages.

And in the case of Catalan, this might prove to be a decisive factor:

While it might be too early to assess whether their impact will be favourable for the survival of Catalan, it is safe to say that the continued success of 
language revitalization will depend, at least partly, on the relationship that Catalan citizens, as well as administrators, politicians and proponents of cultural and linguistic independence in Catalonia, establish with the new immigrants. (Juarros-Daussà and Lanz 2009: 14)

It should be borne in mind that in the Catalan-speaking lands, many of the immigrants speak Spanish as their native language or as the second prestige language in their home countries (according to the official census, in $201030.1 \%$ of immigrants were born in countries where Spanish is an official language). This contingent is moving towards a demo-linguistic situation that is not highly favourable to the maintenance of Catalan. In fact, in recent history, immigration, much more than language shift, has been the leading cause behind the drop in the percentage of the population whose first language is Catalan. ${ }^{3}$ According to EULP/2008 (2009), Catalan as a language of identification even obtains slightly higher percentages as an initial language, i.e. there is a small section of the LI non-Catalan population that affirms that Catalan is its language. The migratory currents of Spanish-speaking people in the 20th century, in a political context characterised by the repression of Catalan, triggered the vernacularisation of Spanish in historically Catalan-speaking lands, where until then Spanish was primarily a second language privileged by the nationalistic language policies of Spain.

Language policy shifted gears in the 1980s (especially in Catalonia and more tentatively and rhetorically in the Balearic Islands and Valencia, despite the recognition of Catalan as a co-official language). Since the Spanish legal system allowed it, the pathway of Catalan revitalisation was taken, whose results have been internationally praised. However, this took place with a population that was linguistically very different to the one that existed four decades earlier:

It turns out that just when recognition of Catalan's official status was being attained, and when the first Catalan recovery measures were being applied, the least Catalan-speaking generation in its entire history was being born in Catalonia. (Vila 2004: 250)

Within this context, some studies point out that Spanish is the language acquired first and the language of everyday use in intergroup relations among alloglot immigrants. For example, an analysis of the figures from the Survey on Living Conditions and Habits of the Population of Catalonia focusing on the immigrant population concludes:

We cannot ignore the fact that the integration of this population mainly takes place through Spanish, and that this noticeably modifies the presence of Catalan in society. (Ajenjo 2008: 61)

\footnotetext{
3 The Catalan-speaking region under French administration and certain areas of Valencia are the exceptions, since they are already undergoing serious processes of language shift (Castelló 2006: 52).
} 
This is the same conclusion reached by Vila (2004: 278) regarding the population of the Barcelona Metropolitan Region, although there it is accentuated by the fact that preceding waves of Spanish-speaking immigrants went there:

In fact, successive editions of the Metropolitan Survey of Barcelona have shown that the majority linguistic evolution of the alloglots in this region veers towards the adoption of Spanish, not Catalan, as their main language. (Vila 2004: 278)

This statement is still fully valid years later: 'The tendency of these new arrivals is to learn Spanish as their everyday language' (Subirats 2010: 90). Likewise, the demo-linguistic data related to declared language competence support these claims:

Among the foreign-born, only $42 \%$ declare that they know how to speak Catalan, while $99.3 \%$ say that they can speak Spanish. (Secretariat of Language Policy 2009: 78)

There are many reasons for this trend in favour of Spanish. The long history of state language planning in favour of Spanish, with extremely aggressive and extended episodes against the other languages, unquestionably plays a key role. However, there is another linguistic factor related to internal dynamics: the tendency to use Spanish in any exchange with people who have been identified as not Catalan, that is, the well-known norm of linguistic convergence (or linguistic subordination) in Spain (Galindo 2006: 86-93). This habit, which is quite widespread, is only heightened by the perception of foreigners through a given accent or physical appearance, and it is an interesting case of a contradiction between representations and uses, since it is easily observable even in people who are self-declared militants on behalf of the preservation of Catalan.

Therefore, the perception that the international migratory flow may pose a threat to Catalan is primarily based on the existence of a monolingual Spanish-speaking immigrant population that resulted from previous waves of immigration in a state which, despite political decentralisation, exerts pressure in favour of Spanish, as well as an international setting which fosters hegemonic languages, and even a bilingual society that has internalised the habit of using Spanish with people it perceives as exogenous. There are two core factors in the linguistic dynamic in the Catalan-speaking lands that contribute to making Catalan fragile in view of a new wave of massive migration: the prior demo-linguistic base, which facilitates the alloglots' assimilation of Spanish, often with social networks in which this language predominates, and the rule of convergence to Spanish i.e., the tendency to change Catalan to Spanish when one assumes that the speaker is not a native speaker of Catalan-, which hinders the new immigrants from learning Catalan. A clear majority rule 
(EULP/2008 2009: 112) that shows no signs of reversing in spite of the change of status of the language:

It may well be that the increased trend to convergence to Spanish has not only not been reversed in recent decades, but on the contrary has continued to spread among new generations of Catalan speakers. (Vila \& Galindo 2012: 43)

However, at the same time the new demo-linguistic situation also contributes opposing factors. It is true that there is a high percentage of Spanish-speaking immigrants, but the majority actually speak other native languages, which in many cases have small demographics, no political recognition and are considerably stigmatised and minoritized. What is more, even though they arrive with no information on the linguistic situation at their destination, today's immigrants seem to show a greater willingness to adapt to the linguistic situation than their predecessors from other areas within Spain:

In the future, language skills in Catalan will only rise, as foreigners are acquiring it much more quickly than immigrants from the rest of Spain. (Querol 2010: 262)

Likewise, quantitative studies show a certain degree of adoption of Catalan as the language of identification by people with another native language. In a benchmark study, the EULP/2008 (2009), 37.2\% answer 'Catalan' to the question 'Tell me what your language is' (which is regarded as their language of identification), while $31.6 \%$ respond 'Catalan' to the question 'Do you remember which language you first spoke at home when you were a child?' (native language). The answer 'Spanish', in contrast, is higher in the question on native language (55\%) than in the language of identification $(46.5 \%)$. Therefore, Catalan gains 5.6 points and the answer 'both' gains 5 points (from 3.8\% to 8.8\%), while Spanish loses 8.5\%. All the other languages also lose ground ( 1.8 points as a whole), which seems to indicate a trend for language shift towards Catalan.

Regarding inter-generational transmission, the survey points to the same phenomenon:

The language uses with grandparents, parents and the eldest child indicate that in Catalonia there is a process of inter-generational language transmission in favour of Catalan since the use of Catalan with the eldest child $(41.7 \%)$ is higher than with the father $(32.3 \%)$ or the mother $(32.6 \%)$ and even more pronouncedly higher than with the maternal grandparents $(29.7 \%)$ and paternal grandparents (30\%). This means that there are nine percentage points of difference in favour of Catalan between the use of this language with the mother and with the eldest child. (Secretariat of Language Policy 2009: 84)

The same trend in favour of identification with Catalan appears in the Barometer of Communication with data from 2010 (FUNDACC-IEC 2011), but here it is much less accentuated: Catalan rose 4.1 points for native language to language of identification, while Spanish fell 
1.6 points and other languages as a group 2.4. However, the study offers a few more details on this issue, which enable us to see that the flows between the native language and the language of identification are neither linear nor simple. Among individuals whose native language is Catalan, $13.3 \%$ identify with another language (almost all of them with Spanish); among individuals whose native language is Spanish, the proportion is $15.1 \%$ ( $14.7 \%$ of whom identify with Catalan); and finally, among those who have declared 'another language' to be their native language, $28.7 \%$ identify with Spanish and $5.7 \%$ with Catalan, a figure that confirms that when there is language shift and/or an interruption in transmission among alloglots, the language adopted in the majority of cases is Spanish.

However, these figures refer only to Catalonia. For Valencia, the Barometer of Communication containing the figures also gathered in 2008 (FUNDACC 2009a) ${ }^{4}$ confirms the same trend, although to a much lesser degree: Valencian is the native language of $19.61 \%$ of the respondents and the language of identification of $22.73 \%$, i.e. it gained 3.12 points. However, Spanish shows hardly any percentage change between the native language and the language commonly used $(74.23 \%$ of the native language and $74.74 \%$ of the language of identification), and in fact all the points gained by Catalan are lost by 'other languages', which drop from $4.38 \%$ as the native language to $2.02 \%$ as the language of identification ( 2.36 points of difference).

For the Balearic Islands, we can examine the FUNDACC 2009b study, which contains data gathered between July 2008 and June 2009. Here the differences between the native language and the language of identification are minimal. Catalan is the native language of $45.26 \%$ of the respondents and the language of identification for $45.06 \%$. Spanish is the native language of $47.22 \%$ and the language of identification for $48.22 \%$. Other languages account for $4 \%$ of native languages and $3.32 \%$ of the languages of identification.

In short, a percentage of the native speakers of other languages identify Catalan as their own language. Who are they? In the case of the FUNDACC-IEC (2011) study on Catalonia, we have seen that there are multiple sources, so the overall data are hopeful for Catalan, yet they give us few details on the dynamics. For Valencia, in fact, we have seen that Spanish has a very similar rate between native language and language of identification, one that is even rising slightly. Therefore, we could interpret this as meaning that, despite the difference in favour of Catalan as the language of identification, it could be due to the influx of alloglots.

However, this kind of interpretation is unquestionably rash and fragile and requires more detailed studies. We can mention yet another change that might be motivated by the presence of recent immigrants. Using figures from the 2006 Survey on Living Conditions and Habits of the Population of Catalonia, Subirats (2010: 80) states that, despite the large presence of alloglots, 'the reproduction of

\footnotetext{
${ }^{4}$ My gratitude to Francesc Xavier Vila and Natxo Sorolla, who allowed me to consult these reports.
} 
Spanish-speaking people is not declining compared to the rise in natives of other languages,' and that despite a sector of the Spanishspeaking Latin American immigrants, 'the relative positions of Catalan and Spanish as native languages remain steady, with a slight drop in Spanish'. This author offers the hypothesis that some descendants of Spanish-speaking immigrants from Spain have now begun to identify with Catalan as a unique hallmark of identity in contrast to the new allogot immigrants:

The phenomenon of bilingualism as a linguistic origin is rising, perhaps in response to a desire to affirm belonging to the Catalan linguistic group by second-generation immigrants in view of the proliferation of other languages. (Subirats 2010: 80)

According to this author's analysis, alloglot immigrants would erode Spanish, in relative terms, not Catalan:

\footnotetext{
However, for the time being, what we can state is that the number of people who consider themselves to be Catalan speakers does not seem to be dropping with the arrival of the new immigrants; rather the number who consider themselves to be exclusively Spanish-speaking is on the wane. (Subirats 2010: 81)
}

What is the specific role of the second generation of recent immigration in this situation? To answer this, research into representations and usage among school-age children is essential. In recent years, researchers have shown considerable interest in these groups, though in general there have been two tendencies. The most traditional approach was not to examine this population and assume that Spanish Spanish was the sole immigration language, whether due to the low percentage of alloglot immigration a few decades ago or the lack of reliable data in more recent times. The more modern trend is to focus the research on the relationship of these groups with Catalan and Spanish. Thus, there have been several studies on alloglot children's degree of acquisition of Catalan, as well as on their representations of Spanish and Catalan languages (for a summary of research in the last decade, see Comajoan et al 2013: 29-37). The data seem to indicate that, on the one hand, children reproduce the patterns of linguistic behaviour already shown by earlier generations, so that 'it is quite likely that many of the alloglot children educated in Catalonia are adopting Spanish as their language in social relationships, but it has to be recognised that we have very few data and so cannot affirm this with confidence' (Galindo \& Vila 2009: 6). The choice, however, would not be due to any specific preference for Spanish, since 'everything suggests that the inclination towards Catalan or Spanish has more to do with the respondents' immediate socio-linguistic environment' (Comajoan et al 2013: 66). Nevertheless, in these age bands, the central importance of school language policy really must be taken into account: 
Despite this variability, the ability to talk in Catalan, at least in the perception of the respondents, is very high in all the areas studied, except for the counties of Baix Cinca and the Llitera, in the central Franja (part of Aragon bordering Catalonia). These data confirm -if such confirmation is still needed - that the school model of immersion in Catalan introduced in Catalonia is still a vehicle that is fundamental to learning the Catalan language; and, in addition, that the schooling in Spanish introduced by the Aragonese Government in the Franja or the linguistic inequality in Mallorca do not provide this ability. (Comajoan et al 2013: 64)

Therefore, we are at a time in which the linguistic role of the alloglots has yet to be defined because the information we have is overly general. We believe that there are alloglot groups that are more likely to adopt Catalan as their language of identification (as their co-language, along with their native language) than others. We believe that the degree of alloglot assimilation (to Catalan or Spanish) is quite high. We also believe that there are certain groups that in no way give up their native language, but that behave as monolingual Spanish speakers in their interactions with other groups (e.g. higherincome European groups whose native language is hegemonic, such as English or German). However, the studies available to us in general treat not only all alloglots, but also all immigrants, as a single entity. It is essential to make distinctions and not forget that we are talking about a proportion of the population which could prove to be decisive. In an estimate based on the place of birth, without taking into account the individuals born in countries where Spanish is the official language, $17 \%$ of the population in Catalonia aged 15 to 44 are alloglots. The native language of just under one-fifth of the people who are likely or ready to have children within the next few years is neither Catalan nor Spanish. Surely this will be a decisive group in Catalonia's linguistic future. This is why we need reliable information. However, recent sociolinguistic research has taken a keen interest in certain aspects of immigrants' linguistic behaviour and little interest in other aspects. ${ }^{5}$ That is, the concern in this realm has been immigrants' linguistic skills in the official languages, but very little attention has been paid to other language skills, and where it has appeared it has been targeted at second academic languages, like English.

\section{Catalan sociolinguistics and the diversity of the linguistic environment}

Sociolinguistic research in Catalonia has essentially stayed within the schema of the Catalan-Spanish linguistic conflict. Even though the

\footnotetext{
${ }^{5}$ And, in fact, some of the quantitative sociological research has shown very little interest at all in the immigrant population. For example, the Centre of Sociological Research (CIS), a governmental body belonging to Spain's Cabinet Office (Ministerio de la Presidencia), includes only Spanish citizens in the sample design: 'the CIS samples [...] refer to a population universe defined by the characteristics of political citizenship; that is, the population represented in the samples are individuals with Spanish citizenship who are legally of age' (Castelló 2006: 8). This also holds true for the demo-linguistic studies conducted by this institution.
} 
presence of the category 'other languages' has gradually gained prominence in demo-linguistic studies in the past decade, in fact very little attention has been paid to the details of it. Below we shall mention two factors that we believe to be symptomatic.

\subsection{Concealment of languages}

It is highly significant that the demo-linguistic surveys only offer the respondents a minimum set of choices, and that these choices are almost always official or state languages and/or languages with enormous demographic importance. For example, in the EULP/2008 survey (2009), the answer choices offered in the questions on the language of identification, native language and language most often used were 'Catalan' (Valencian/Balearic), 'Spanish', 'Catalan (Valencian/Balearic) and Spanish equally', 'Aranese' and 'others (please specify the language or combination)'. In the question on knowledge of other languages, the following choices were offered: 'Galician', 'Basque', 'French', 'English', 'German', 'Arabic', 'I don't speak any other languages' and 'others (please specify)'. There was also a specific part on knowledge of English and French. This procedure actually fosters the invisibilisation of linguistic diversity. There are no languages on the list that we know are spoken in Catalan-speaking areas yet are often hidden, like Tamazight, Punjabi and Guarani, ${ }^{6}$ while there is a box for English, German and French, which unquestionably no native would fail to note properly in the section for 'others (please specify)'. The fact that the concealment phenomena typical of stigmatised languages (Comellas et al. 2010) are not taken into account is symptomatic of the scant interest in these 'other languages' despite the empathy that might be prompted by the fact that they share with Catalan minoritisation in their respective states. One would think that a little research before drawing up the questionnaire would alleviate this problem. Thus, the languages that we know are present in the environment, but are little recognised, could be made explicit, whereas languages such as English or German, as they are prestigious enough for their speakers to include in their replies without the slightest hesitation, do not have to be included explicitly in a questionnaire.

\subsection{Underestimation of alloglots in statistical studies}

It is valid to suspect that demo-linguistic studies have underestimated the proportion of alloglots. Table 1 shows the percentage of alloglots given in two benchmark studies and the same figure inferred from the census in the same year according to place of birth. All the figures refer to people over the age of 15 living in Catalonia:

\footnotetext{
${ }^{6}$ Guarani, the majority language in Paraguay, though still minoritised, is an exemplary case. The speakers express an extremely low level of inter-generational transmission and often 'claim that their language is Spanish' (Fabà 2010: 69).
} 


\section{[TABLE 1 NEAR HERE]}

Table 1: Percentage and inference of the total number of alloglots in two demolinguistic studies on the population of Catalonia and in the census according to place of birth.

It should be borne in mind that the estimates of the number of alloglots based on the census were rounded down, since they only took into account the individuals born in countries where the official language is not Spanish. Therefore, no speakers of the Amerindian languages born in Latin-American countries are included in the figures (although in the case of Paraguay, for example, they are probably the majority). What does this underestimation in the demo-linguistic surveys tell us? It is very likely that the results for people born outside Spain or who are not Spanish nationals could be partially biased by under-representation of alloglot sectors and, consequently, overrepresentation of Spanish speakers.

The distance between the statistical estimate and the demographic estimate may be an indication of shortcomings that would advise complementing quantitative studies with other methodological tools. The first hypothesis that could explain the underestimation of the percentage of alloglots in the immigrant population has to do with how data are gathered. Generally speaking, the professionals charged with conducting the surveys have questionnaires in Catalan and Spanish, while in the case of telephone surveys they offer the respondents the choice of being asked in one of these two languages. It seems clear that in a random sample, this could contribute to leaving people with low language competence in Catalan or Spanish outside the survey. ${ }^{7}$ Since until now the most meticulous studies, such as the EULP/2008 (2009) - which rebalances the sample size according to several variables, including place of birth -, made no distinctions between Spanish speakers and alloglots, the risk of prioritising Spanish-speaking immigrants remains. Precisely the EULP/2008 (2009) provides us a clue along these lines. The sample was designed to have a list of specific individuals before the fieldwork began, with a large number of possible substitutes who were also hand-picked in advance. However, due to a variety of problems (refusal to answer, impossibility of locating the person, etc.), only $37.8 \%$ of the first-choice individuals ended up as part of the sample. In another $22.9 \%$ of the cases, the first substitute answered, and up to $16.4 \%$ of the answers were provided by the fifth substitute. Of the 18,857 people who were contacted (to get the 7,140 valid surveys in the final sample), 793 stated that they were unable to answer and 1,746 refused to respond. It is plausible to believe that one of the reasons for this refusal and even for the declaration of being unable

\footnotetext{
${ }_{7}$ The bias prompted by the act of selecting the sample only among people with a landline telephone, which certainly prejudices against immigrants, was rectified a long time ago.
} 
to respond was the respondents' low level of competence in the survey languages. ${ }^{8}$

A second hypothesis that would explain the underestimation of other languages in these studies is based on that we only have information on what the respondents say that they know how to do or actually do, without any other external indicator. This problem is only further accentuated when the surveys are addressed not to the general population but to institutions, where the desire or need to respond what is assumed to be the right answer, more than the truth, is accentuated. F. Xavier Vila (2004: 262) mentions this with respect to the use of Catalan in education:

\begin{abstract}
What is the current status of Catalan as the language of education? Paradoxically, right now it is more difficult to state with confidence than it was years ago. Since Catalan was enshrined as a 'vehicle of normal expression' (in article 20 of the Law on Language Policy 1/1998 of the Parliament of Catalonia), the schools in Catalonia report - totally understandably - that their uses of Catalan conform to the law.
\end{abstract}

Only in-depth qualitative studies can prove the veracity of the quantitative studies. ${ }^{9}$ However, they are not able to determine statistically the magnitude of the bias prompted by exaggerated or false answers. Regardless, field experience demonstrates that the respondents conceal languages, that they use glotonyms that are at the very least ambiguous or that they answer according to the expectations that they assume the interviewer or the society around them to have (Comellas et al. 2010).

\title{
4. Conclusion
}

Based on the hypothesis that the demo-linguistic studies conducted in the Catalan-speaking area have not been sufficiently mindful of its linguistic diversity - which has risen dramatically in recent years through immigration -, we have attempted to demonstrate that in today's circumstances, all the people whose native language is neither Catalan nor Spanish could have a significant influence on the sociolinguistic dynamic in the decades to come. However, in order to properly understand this issue, we believe we must acquire considerably more knowledge of the vast heterogeneity shown by the alloglots, as well as more accurately estimate the size of this group. The demographic data from the census provide us with indications of not only quantitative underestimation, but also the vast complexity of these human groups,

\footnotetext{
${ }^{8}$ This problem has been at least partially rectified, as the recently published results of the EULP-2013 survey show. This survey is also included in the table and its findings are much closer to the calculations based on the census. It seems that under-estimation is being corrected in the most recent studies.

${ }^{9}$ Even in in-depth personal interviews, there have been reports of serious difficulties in uncovering the "lies" uttered by informants (Calvet 1999: 104).
} 
whose age pyramids enable us to predict very different future projections that are directly related to language transmission.

Today, language planning that does not take the diversity that exists into account is inevitably less efficient. But more than that, its legitimacy is also jeopardised. Catalan area has speakers of dozens of minoritised, disparaged, abused languages. It is incoherent that a community that has suffered and to some extent still suffers from the consequences of this kind of policy and mentality should ignore the problems of others and only be concerned with its own status.

Catalan sociolinguistics, which in general is highly committed not only to scientific research but also to activism in the preservation of Catalan, is showing an increasingly statist tendency. It has almost always approached planning based on the idea that 'Catalan would be adopted by those who do not speak it because its institutionalised use, with its concomitant higher prestige, would lead them to emulate [...]. Therefore, there was no need to act on specifically interpersonal use' (Aymà 2010: 28). As a result, linguistic diversity has sometimes been understood in its Swiss, Belgian or Canadian sense as a mosaic of monolingualisms, and a situation of dynamic multilingual balance has not been considered possible. The classical theory of language normalisation (Aracil 1982) starts from the idea that all language contact evolves towards the replacement of one and the hegemony of the other; therefore, the preservation of one of them ultimately necessitates the eradication of the other. From this perspective, introducing other languages in the Catalan-speaking realm is rather irrelevant in view of the socio-political circumstances, and the essential conflict remains between Catalan and Spanish.

From our point of view, viewing the situation in these terms most likely implies assuming the attrition and consequent disappearance of Catalan in the short term. Given the conditions of the vernacularisation of Spanish in the Catalan-speaking lands (which is more extensive in Valencia, but widespread everywhere), we believe that it is necessary to seek different language planning proposals that entail new arguments on the legitimisation of revitalisation beyond the nation-state (Comellas 2011), and new strategies of multilingual coexistence and preservation. In this sense, the linguistic diversity present today in the Catalan-speaking lands is an opportunity to construct language representations and practices whose goal is to build networks of communication that make it possible to both adopt the local historical language and transmit native languages.

The goal is not only to pay others the respect Catalan speakers demand; rather it is also to recognise and value these languages in order to achieve complicity and find allies in the preservation of Catalan within the framework of preservation of linguistic and cultural diversity. What threatens the Catalan is not difference but the opposite: homogenisation. As Junyent (1998: 110) says, 'Difference in itself is never the source of conflict: however, it is when difference is not respected'. 


\section{References}

Ajenjo, M., Blanes, A., Bosch, J., Parella, S., Recio, A., San Martin, J., Sintes, E. (2008). Les condicions de vida de la població immigrada a Catalunya. Barcelona: Fundació Jaume Bofill.

Aracil, L. V. (1982). Conflicte lingüístic i normalització lingüística a l'Europa nova. In Papers de sociolingüística (pp. 23-57). Barcelona: La Magrana.

Aymà, J. M. (2010). El català, al carrer. Barcelona: UOC.

Barrieras, M. (2013) La cruïlla del multilingüisme: les llengües dels catalans al segle XXI. DivËrsia: Revista de la Càtedra sobre Diversitat Social de la Universitat Pompeu Fabra, 3: 2-37.

Calvet, L.-J. (1999) La guerre des langues et les politiques linguistiques. Paris: Hachette.

Castelló, R. (2006). Els estudis sobre la situació sociolingüística al País Valencià. Barcelona: IEC.

Comajoan, L.; Vila, F.-X.; Bretxa, V.; Sorolla, N.; Tenorio, X. \& Melià, J. (2013). Els usos lingüístics en família i amb amics de l'alumnat autòcton i al-lòcton de sisè de primària a Catalunya, Mallorca $\mathrm{i}$ la Franja. In F.-X. Vila \& E. Salvat (eds.). Noves immigracions $i$ llengües (pp. 29-75). Barcelona: AEAU.

Comellas, P., Barrieras, M., Monrós, E., Cortès-Colomé, M., Fidalgo, M., Junyent, M.C. (2010). Descobrir les llengües de la immigració: ocultació, prejudicis i altres malentesos. Llengua, Societat $i$ Comunicació 8: 54-62.

Comellas, P. (2011). A hipótese da morte da lingua. Grial, 190: 63-69.

EULP/2008 (2009). Enquesta d'usos lingüístics de la població 2008. Retrieved from <http://idescat.cat/p/eulp2008>.

EULP/2013 (2014). Els usos lingüístics de la població de Catalunya:

Principals resultats de l'Enquesta d'usos lingüístics de la població 2013. Barcelona: Generalitat de Catalunya.

Fabà, A. (2010). Llengua inicial i llengua d'identificació dels nats a l'estranger, a Catalunya. Llengua, Societat i Comunicació 8: 6371.

Fishman, J. A. (1991). Reversing Language Shift. Clevedon: Multilingual Matters.

FUNDACC-IEC (2011). Coneixements $i$ usos del català a Catalunya el 2010: dades del Baròmetre de la Comunicació i la Cultura. Retrieved from: <http://blocs.iec.cat/cruscat/2011/03/31/coneixements-i-usosdel-catala-a-catalunya-el-2010-dades-del-barometre-de-lacomunicacio-i-la-cultura/>.

Galindo, M. (2006). Les llengües a l'hora del pati: usos lingüístics en les converses dels infants de primària de Catalunya. Doctoral thesis. Barcelona: Universitat de Barcelona.

Galindo, M.; Vila, F.-X. (2009). Els factors explicatius dels usos lingüístics informals entre l'alumnat català: Ilengua inicial, xarxes socials, competència i llengua vehicular d'ensenyament. Noves SL.: Revista de sociolingüística, 2009-1. 
Juarros-Daussà, E., Lanz, T. (2009). Re-thinking balanced bilingualism: The impact of globalization in Catalonia. Language Problems \& Language Planning 33/1: 1-21.

Junyent, M. C. et al. (2005). Les llengües a Catalunya: quantes llengües s'hi parlen? Barcelona: Octaedro.

Larreula, E. (2002). Dolor de Ilengua. València: Tres i Quatre.

Pradilla, M. A., Sorolla, N. (2012). Informe sobre la situació de la Ilengua catalana (2011). Barcelona: Observatori de la Llengua Catalana.

Querol, E. (ed.) (2007). Llengua $i$ societat als territoris de parla catalana a I'inici del segle XXI: L'Alguer, Andorra, Catalunya, Catalunya Nord, la Franja, Illes Balears i Comunitat Valenciana. Barcelona: Secretaria de Política Lingüística.

Querol, E. (2010). Enquesta demogràfica 2007: nova font, noves dades sociolingüístiques. Revista de Llengua i Dret 53: 243-264.

Ros, A. (2006). Catalunya davant el nou repte migratori. In F. X. Vila, E. Boix, N. Alturo (ed.). Integrar, des de la fragilitat?: Societats plurilingües davant els reptes de les immigracions multilingües: Suïssa, Brussel/les, Luxemburg, Quebec i Catalunya (pp. 51-66). Barcelona: IEC.

Secretaria de Política Lingüística (2009). Les llengües a Catalunya: resultats de l'Enquesta d'usos lingüístics a la població 2008. Llengua i Ús 45: 75-91.

Strubell, M. (2001). Catalan a Decade Later. In J. A. Fishman (ed.). Can Threatened Languages Be Saved?: Reversing Language Shift Revisited (pp. 260-283). Clevedon: Multilingual Matters.

Subirats, M. (2010). Els trets lingüístics de la població metropolitana. Papers, 52: 78-90.

Tilmatine, Mohand (2002-2003). El amazigue (bereber) en el contexto de la inmigración: ¿hacia un proceso de reconocimiento? AlAndalus Magreb: Estudios Árabes e Islámicos 10: 265-280.

Vila, F. X. (2004). Hora de fer balanç?: elements per valorar les polítiques lingüístiques a Catalunya en el període constitucional. Revista de Llengua i Dret 41: 243-286.

Vila, F. X., Galindo, M. (2012). Sobre la història i l'extensió de la norma de convergència lingüística a Catalunya. In F. X. Vila (ed.). Posar-hi la base: usos $i$ aprenentatges lingüístics en el domini català (pp. 31-45). Barcelona: IEC. 